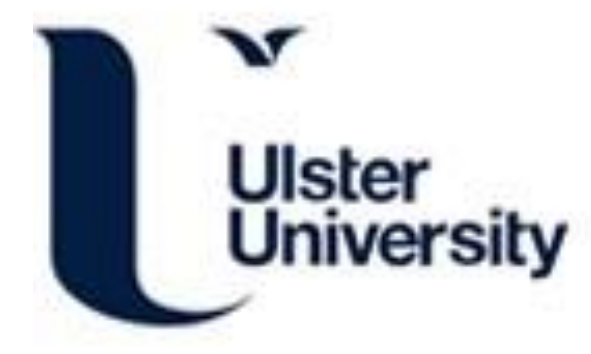

\title{
Biodegradation potential of crude petroleum by hydrocarbonoclastic bacteria isolated from Soummam wadi sediment and chemical-biological proprieties of their biosurfactants
}

Yalaoui-Guella, D., Fella-Temzi, S., Djafri-Dib, S., Madani, K., Banat, I., \& Brahmi, F. (2020). Biodegradation potential of crude petroleum by hydrocarbonoclastic bacteria isolated from Soummam wadi sediment and chemical-biological proprieties of their biosurfactants. Journal of Petroleum Science and Engineering, 184, 1-7. [106554]. https://doi.org/10.1016/j.petrol.2019.106554

Link to publication record in Ulster University Research Portal

Published in:

Journal of Petroleum Science and Engineering

Publication Status:

Published (in print/issue): 31/01/2020

DOI:

10.1016/j.petrol.2019.106554

\section{Document Version}

Author Accepted version

\section{General rights}

Copyright for the publications made accessible via Ulster University's Research Portal is retained by the author(s) and / or other copyright owners and it is a condition of accessing these publications that users recognise and abide by the legal requirements associated with these rights.

\section{Take down policy}

The Research Portal is Ulster University's institutional repository that provides access to Ulster's research outputs. Every effort has been made to ensure that content in the Research Portal does not infringe any person's rights, or applicable UK laws. If you discover content in the Research Portal that you believe breaches copyright or violates any law, please contact pure-support@ulster.ac.uk. 


\section{Journal Pre-proof}

Biodegradation potential of crude petroleum by hydrocarbonoclastic bacteria isolated from Soummam wadi sediment and chemical-biological proprieties of their biosurfactants

Drifa Yalaoui-Guellal, Samira Fella-Temzi, Salima Djafri-Dib, Fatiha Brahmi, Ibrahim

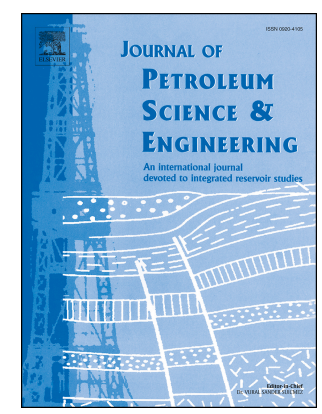
M. Banat, Khodir Madani

PII: S0920-4105(19)30975-1

DOI: https://doi.org/10.1016/j.petrol.2019.106554

Reference: PETROL 106554

To appear in: Journal of Petroleum Science and Engineering

Received Date: 28 January 2019

Revised Date: 8 July 2019

Accepted Date: 1 October 2019

Please cite this article as: Yalaoui-Guellal, D., Fella-Temzi, S., Djafri-Dib, S., Brahmi, F., Banat, I.M., Madani, K., Biodegradation potential of crude petroleum by hydrocarbonoclastic bacteria isolated from Soummam wadi sediment and chemical-biological proprieties of their biosurfactants, Journal of Petroleum Science and Engineering (2019), doi: https://doi.org/10.1016/j.petrol.2019.106554.

This is a PDF file of an article that has undergone enhancements after acceptance, such as the addition of a cover page and metadata, and formatting for readability, but it is not yet the definitive version of record. This version will undergo additional copyediting, typesetting and review before it is published in its final form, but we are providing this version to give early visibility of the article. Please note that, during the production process, errors may be discovered which could affect the content, and all legal disclaimers that apply to the journal pertain.

Crown Copyright $@ 2019$ Published by Elsevier B.V. All rights reserved. 


\section{Journal Pre-proo}

1 Biodegradation potential of crude petroleum by hydrocarbonoclastic bacteria isolated

2 from Soummam wadi sediment and chemical-biological proprieties of their

3 biosurfactants

4

\section{1- Drifa Yalaoui-Guellal (Corresponding author)}

6 Faculty of Nature Sciences and Life and Earth Sciences, University of Bouira , Bouira

$7 \quad 10000$, Algeria

8 Laboratory of Biomathematics, Biochemistry, Biophysics and Scientometry, Faculty of

9 Nature Sciences and Life, University of Bejaia, Bejaia 06000, Algeria.

\section{Email: d.guelal@univ-bouira.dz}

\section{2- Samira Fella-Temzi}

Laboratory of Biomathematics, Biochemistry, Biophysics and Scientometry, Faculty of Nature Sciences and Life, University of Bejaia, Bejaia 06000, Algeria.

Email :sam1978@yahoo.fr

\section{3- Salima Djafri-Dib}

Faculty of Nature Sciences and Life, University of Bejaia, Bejaia 06000, Algeria.

Email : dib-salima@yahoo.fr

\section{4- Fatiha Brahmi}

Laboratory of Biomathematics, Biochemistry, Biophysics and Scientometry, Faculty of Nature Sciences and Life, University of Bejaia, Bejaia 06000, Algeria.

Email : fatiha2002@yahoo.fr

\section{5- Ibrahim M. Banat}

School of Biomedical Sciences, University of Ulster, Coleraine, County Londonderry, Northern Ireland, UK. Email: $\underline{\text { im.banat@ulster.ac.uk }}$

\section{6- Khodir Madani}


1 Laboratory of Biomathematics, Biochemistry, Biophysics and Scientometry, Faculty of

2 Nature Sciences and Life, University of Bejaia, Bejaia 06000, Algeria.

3 Email: Madani28dz202@yahoo.fr

\section{$4 \quad$ 1. Introduction}

5 Organic pollutants such as petroleum hydrocarbons contaminate the water column and

6 sediments around the world, causing hence a considerable number of adverse effects on

7 human health, air and water quality, ecosystem deterioration, biosystems biodiversity and

8 food chains contamination (Stauffert, 2011). Chemical and physical treatment processes have

their limits because of their cost or their secondary impact on the environment. Biological treatments technologies are currently subject of a great deal of investigations worldwide. These bioremediation technologies are mainly based on the use of microorganisms to extract, separate or degrade hydrocarbon and other organic contaminants. The diversity of bacteria involved in the biotransformation processes is very important, including both Gram-negative and Gram-positive ones and grouping together almost all phylogenetic clads (Samanta et al., 2002). These microorganisms naturally play a crucial role in the fate and degradation of hydrocarbons in ecosystems and are widely distributed in marine environments (water column and in sediments) (Técher, 2011; Barbato et al., 2016). Bacteria from soils contaminated with hydrophobic molecules often synthesize bimolecular compounds called biosurfactants, typically induced by hydrocarbon presence, allowing them to use these hydrocarbons as sources of carbon and energy.

These biosurfactants are very interesting tools in many industrial and environmental applications (Fracchia et al., 2015) and can be considered as substitutes of chemical surfactants due to their biodegradability, biocompatibility and lack of toxicity (Mulligan et al., 2014; De Almeida et al., 2016). Among the various marine bioactive compounds, microbial biosurfactants (BS) are of great importance because of their structural and functional diversity 
1 and their industrial applications. Marine microbial biosurfactants are such metabolites with many interesting properties (Banat et al., 2010; Wicke et al., 2000). It is in this perspective that this work was conducted, where we exploited the bacterial strains that were isolated from the sediments of the Soummam wadi that were exposed to contamination by organic pollutants from various sources.

The main objectives of our work were: the determination of biodegradability potential of crude oil by hydrocarbonoclastic strains isolated from sediments of the Soummam wadi of Bejaia, Algeria; the production and characterization of biosurfactants. We also aimed to determine the chemical and biological profiles of biosurfactants produced by these isolated and identified strains.

\section{Material and methods}

\subsection{Samples collection}

The sediments samples were obtained from the bed of the Soummam wadi at the Skala bridge, Bejaia, Algeria (latitude: $36^{\circ} 43^{\prime} 58.89$ "N, longitude: $4^{\circ} 04^{\prime} 04.47^{\prime \prime} \mathrm{E}$ ). The samples were taken at depths up to $60 \mathrm{~cm}$ and were collected by inserting a sterile corer into the sediments. Then, samples were transferred into a sterile bottle and transported immediately to the laboratory.

\subsection{Physico-chemical analysis of sediments}

Different physical and chemical analysis of sediments samples were carried out using standard methods to determined $\mathrm{pH}$, conductivity, humidity, organic matter, total nitrogen by Kjeldahl method and granulometry (particle size).

\subsection{Isolation of microorganisms and biosurfactant production evaluation}

Hydrocarbonoclastic bacteria strains were isolated from the sediment samples of Soummam wadi using an enrichment technique method in mineral salt medium (MSM), with various hydrocarbons as the sole carbon source. The strains were characterized as Alcaligenes 
1 faecalis, Cellulosimicrobium sp., and Rhodococcus ruber on the basis of phenotypic

2 characterization and identification by MALDI-TOF Mass Spectrometry. Detection of

3 biosurfactants production by these isolates was carried out by oil spreading test and measuring

4 the emulsification index (E24) and were maintained as described previously (Yalaoui-Guellal

5 et al., 2018).

\subsection{Determination of biodegradability potential of Hydrocarbonoclastic bacteria strains}

Biodegradation of petroleum samples using single pure culture was carried out in $250 \mathrm{~mL}$ Erlenmeyer flasks containing $100 \mathrm{~mL}$ of mineral-salts-medium (MSM) (Ijah et Antai, 2003) containing $2 \mathrm{~mL}$ of crude petroleum from Hassi Masseaoud of Algeria (light crude petroleum) and inoculated with $2.0 \%(\mathrm{v} / \mathrm{v})$ of the bacterial monoculture prepared in sterile physiological water and adjusted to obtain the same concentration for all monocultures. Control flasks were also placed containing only $100 \mathrm{~mL}$ of medium and $2 \mathrm{~mL}$ of crude oil. All culture flasks were incubated at $30^{\circ} \mathrm{C}$ with shaking at $130 \mathrm{rpm}$. The treatments were carried out in triplicate and incubated for up to 12 days and samples were analyzed every 3 days.

\subsubsection{Determination of total bacterial biomass}

The microbial population was determined by total bacterial biomass method using the dry weight of the cells. At the end of incubation of each period, the samples were centrifuged at $13.000 \mathrm{rpm}$ for $15 \mathrm{~min}$ (Sigma 2-16 PK), then the pellet was recovered after washing with distilled water and then dried at $80^{\circ} \mathrm{C}$. Biomass was estimated in $\mathrm{mg} / \mathrm{mL}$.

\subsubsection{Determination of petroleum biodegradation by Hydrocarbonoclastic bacteria} strains

The degraded total petroleum was estimated by measuring the residual crude oil, it was recovered by double extraction with diethyl ether $(30 \mathrm{~mL})$ and the solvent was separated after $1 \mathrm{~h}$ and allowed to evaporate in the ventilated oven set at $40^{\circ} \mathrm{C}$. The total biodegradation rate was determined gravimetrically using the equation described by Chaillan et al. (2004): 


$$
\% B=[(W 1-W C) / W 1] * 100
$$

1 Where, $\% \mathrm{~B}$ is the percentage of biodegradation of crude petroleum, $\mathrm{W}_{1}$ is the residual oil

2 weight in the sterile control and $\mathrm{W}_{\mathrm{C}}$ is the residual oil weight in the bacterial culture.

3

4

\subsection{Production, extraction and lyophilization of crude biosurfactants}

The MSM containing 2\%(v/v) of glucose and $0.1 \mathrm{~g} / \mathrm{L}$ of yeast extract was used as the culture medium for biosurfactant production experiments. Biosurfactant production was carried out as described in our previous study (Yalaoui-Guellal et al., 2018).

\subsection{Chemical profile of biosurfactant}

\subsubsection{UV-Visible spectrophotometer analysis and Thin layer chromatography (TLC)} analysis

A scanning absorption spectrum UV-Visible using UV-1800 SHIMADZU UV Spectrophotometer (Duisburg, F.R. Germany), was carried out with a wavelength ranging from 190-400 nm, in order to examine the presence of proteins and nucleic acids. For Thin layer chromatography (TLC) analysis, a small amount of the lyophilized crude extract was dissolved in chloroform, and analyzed by TLC using silica gel60coated glass sheet (Silica gel $60 \mathrm{~F}_{254}$, MERCK, Germany). The plates were developed in a solvent system: chloroformmethanol-acetic acid $(6.5 / 1.5 / 0.2 ; \mathrm{v} / \mathrm{v} / \mathrm{v})$ for the detection of glucolipid and in a system: chloroform-methanol-water $(65 / 15 / 4 ; \mathrm{v} / \mathrm{v} / \mathrm{v})$ to reveal the lipopeptide. When the development of plates has achieved, these last were heated at $110^{\circ} \mathrm{C}$ for $5-20 \mathrm{~min}$. Spots were revealed by spraying with: (a) anthrone reagent $\left(0.125 \mathrm{mg}\right.$ in $\left.63 \mathrm{~mL} \mathrm{H}_{2} \mathrm{SO}_{4}, 25 \mathrm{~mL} \mathrm{H}_{2} \mathrm{O}\right)$ for the detection of sugar moieties, for glycolipids system; (b) solution ninhydrine (35 mg in $100 \mathrm{~mL}$ acetone) for the detection of compounds with free amino groups for the lipopeptide system. (Smyth et al., 2014; Noparatet al., 2014).

\subsubsection{Determination of protein and lipid content}


1 Total protein content of biosurfactants was determined according to the method described by

2 Bradford (1976) using Bovine Serum Albumin as standard. The lipid content was estimated

3 by gravimetric estimation using the method of Bligh and Dyer (1959).

\subsubsection{Fourier Transform Infrared Spectroscopy (FTIR) Characterization}

FTIR spectroscopy using the $\mathrm{KBr}$ pellet method was performed in this study to determine the chemical nature and functional groups of crude biosurfactant extracts using Fourier Transformed Infrared Spectrophotometer (IRaffinity-1, SHIMADZU). FTIR spectra were obtained in the spectral region $4000-400 \mathrm{~cm}^{-1}$ (Das et al., 2008).

\subsection{Biological activities of biosurfactant}

\subsubsection{Antimicrobial activity}

Crude biosurfactants extract was prepared in $1 \%(\mathrm{v} / \mathrm{v})$ methanol and passed through a $0.22 \mu \mathrm{m}$ membrane filter and stored in sterile glass bottles. These stock solutions were utilized for antimicrobial testing as reported by Brahmi et al. (2016).

Antimicrobial assay of biosurfactants was investigated against test bacteria, filamentous fungi and yeast (Table 1) using a direct antagonism spot test. Each microbial inoculum was prepared from a pure and young culture (18-24 $\mathrm{h}$ for bacteria and $24-48 \mathrm{~h}$ for fungi).These cultures were adjusted at 0.5 McFarland turbidity scale $\left(10^{8} \mathrm{CFU} / \mathrm{mL}\right)$. Two $\mathrm{mL}$ of standardized suspensions of the microorganisms were deposited in Petri dishes contained 18 $\mathrm{mL}$ of Mueller-Hinton agar for bacteria strains or Potato Dextrose Agar for fungi strains.

The plates were incubated at $37^{\circ} \mathrm{C}$ for $24 \mathrm{~h}$ for bacteria strains and at $30^{\circ} \mathrm{C}$ for $48 \mathrm{~h}$ for fungi strains. The inhibition zones around the spots were measured. All the tests were carried out in triplicates and the diameter of microbial growth inhibition halo was measured in millimeters and was represented as the standard error of the mean (SE).

\subsubsection{Antioxidant assay}


1 Antioxydant activity of biosurfactants was carried using Radical Scavenging Activity of

2 DPPH (2,2-diphényl-1-picrylhydrazyl) Method descrited by Blois (1958) with some

3 modifications and total antioxidant capacity using the method described by Brahmi et al.

4 (2012).

5 For the scavenger effect of biosurfactants towards $\mathrm{DPPH}^{\circ}$ radical, $0.5 \mathrm{~mL}$ of the DPPH

6 solution $(0.1 \mathrm{mM})$ was mixed with $1.5 \mathrm{~mL}$ of each crude biosurfactant at different concentrations $(1-5 \mathrm{mg} / \mathrm{mL})$. The mixtures were stirred vigorously and left at room temperature in the dark for $30 \mathrm{~min}$. The absorbance of the solutions was then measured at 517 (SpectroScan $50 \mathrm{UV}$-Vis Spectrophotometer) and the percentage inhibition of the $\mathrm{DPPH}^{\circ}$ radical was calculated using the following equation:

$$
\text { Scavenger effect of } \mathrm{DPPH}^{*}(\%)=\left[\left(A_{0}-A_{1}\right) / A_{0}\right]^{*} 100
$$

Where $\mathrm{A}_{0}$ was the control absorbance and $\mathrm{A}_{1}$ was the sample absorbance. The antiradical activity was expressed in $\mathrm{IC}_{50}(\mu \mathrm{g} / \mathrm{mL})$, which is the concentration required to cause a $50 \%$ inhibition. A low $\mathrm{IC}_{50}$ value corresponds to a high antioxidant activity of biosurfactant. Butylated Hydroxyanisole (BHA) was used as standard.

Reduction of phosphomolybdenum was calculated to determine the total antioxidant capacity of biosurfacants by using the method described by Brahmi et al. (2012). $2 \mathrm{~mL}$ of the Molybdate reagent $(4 \mathrm{mM}$ ammonium molybdate, $28 \mathrm{mM}$ sodium phosphate and $0.6 \mathrm{mM}$ sulfuric acid) was added to $200 \mu \mathrm{L}$ of each biosurfactant at different concentrations (1-5 $\mathrm{mg} / \mathrm{mL}$ ). After stirring, the tubes were incubated in the water bath at $90^{\circ} \mathrm{C}$ for $90 \mathrm{~min}$. After cooling, measurements were carried out at $695 \mathrm{~nm}$ (SpectroScan 50 UV-Vis Spectrophotometer). The results were expressed in $\mathrm{IC}_{50}(\mu \mathrm{g} / \mathrm{mL})$. The biosurfactants ability of biosufacts to reduce Mo (VI) is compared with BHA.

\subsubsection{Metal biosorption activity}


1 The method used to determine the metal $(\mathrm{Pb})$ biosorption capacity by the biosurfactant was

2 that of Shuhong et al. (2014). The $\mathrm{Pb}^{2+}$ solution (100 ppm) was prepared by dissolving the

3 calculated amount of lead nitrate in distilled water. Adsorption experiments were carried out

4 by adding $10 \mathrm{~mL}$ of the metal solution in $40 \mathrm{~mL}$ of each crude biosurfactant solution to have a

5 final biosurfactant concentration of $1 \%(\mathrm{w} / \mathrm{v})$. A control was made with the metal solution.

6 All experiments were incubated at room temperature with stirring (200 rpm) for $3 \mathrm{~h}$. To study the $\mathrm{pH}$ effect on biosurfactant adsorption, the $\mathrm{pH}$ was adjusted at 3 and 7 . At the end of incubation, the samples were centrifuged at $10.000 \mathrm{rpm}$ and then filtered through a $0.45 \mu \mathrm{m}$ cellulose acetate membrane filter. The $\mathrm{Pb}^{2+}$ residuals in the supernatants were determined by atomic adsorption spectrophotometer (AAS) (Thermo Scientific, iCE 3000 SERIES, AA Spectrometer).The biosorption capacity, Qe $(\mathrm{mg} / \mathrm{g})$, was determined by the following equation:

$$
Q e=\frac{V(C i-C e)}{W}
$$

Where $\mathrm{Ci}$ and are the initial (control) and final (sample) metal $(\mathrm{Pb})$ concentrations in the solutions $(\mathrm{mg} / \mathrm{L})$, respectively, $\mathrm{V}$ is the sample volume $(\mathrm{L})$, and $\mathrm{W}$ is the biosurfactant $\operatorname{mass}(\mathrm{g})$.

\subsection{Statistical analysis}

Data from all experimental were presented as the mean \pm standard deviation (SD) and were represented with error bars and one-way analysis of variance (ANOVA) was applied to ascertain significant differences between crude biosurfactants group and control. Differences were considered to be statistically significant at $P<0.05$. All analysis were performed using Statistica software (version 5.1).

\section{Results and discussion}

\subsection{Physico-chemical analysis of sediments}


1 The sediments samples examined had neutral $\mathrm{pH}$ of $7.37 \pm 0.05$. Comparing our results with

2 those of other studies, we find that our results are almost similar to those provided by

3 Carpentier et al. (1999), where the $\mathrm{pH}$ varies between 7.06 and 7.76 in the month of

4 December and from 7.2 to 8.2 in the month of March in the Seine basin (France). They have a

5 total nitrogen content of $0.158 \pm 0.008 \%$. This result was very important compared to the

6 result obtained by Cunqi et al. (2007), where the total nitrogen content was varied between

$7 \quad 0.21$ and 0.68 g. $\mathrm{kg}^{-1}(0.021$ and $0.068 \%)$ in the surface layer sediments in the Chongming

8 Dongtan of the Yangtze Estuary (China).

According to Hwang and Lee (2002) the studied sample sediments had high humidity of 28.1 $\pm 0.2 \%$. The sediment sample had a very high organic matter content $(11.9 \pm 0.13 \%)$. Our results were almost similar to those found by Zhang et al. (2008), which recorded important values (49 and 6.3\%) respectively in the Victoria estuary (China).

According to the scale of salinity which is based on the electrical conductivity of aqueous extract (Richards, 1969), the sediment sample was considered slightly salty having conductivity between 0.6 and $1.2 \mathrm{mS}(1.01 \pm 0.03 \mathrm{mS})$. Kretschmara et al. (2008), measured an electrical conductivity of between 0.956 and $1.164 \mathrm{mS} / \mathrm{cm}$ in the sediments of various courses in Amsterdam (Holland). The results of particle size analysis (granulometric) of sediment samples revealed that the sediment sample had a mainly clay texture $(37.93 \pm 0.43 \%)$ which have a strong adsorption of water and organic matter. This result confirms that granulometry can play an important role on sediment dryness (Zhou, 2009),

\subsection{Hydrocarbonoclastic bacteria strains isolated and their biodegradation potential}

The analysis of the potential of the biodegradability of Alcaligenes faecalis, Cellulosimicrobium and Rhodococcus ruber has demonstrated the ability of the latter to use the crude oil for their carbon source. The biodegradation percentage of the crude petroleum by Rhodococcus ruber, Alcaligenes faecalis and Cellulosimicrobium sp. has reached the 
maximum of $56.54 \pm 1.17 \%, 52.66 \pm 1.15 \%$ and $49.69 \pm 1.2 \%$, respectively, at the 12 th day of incubation (Figure 1). The results for pure bacterial cultures showed a significant growth rate with the highest dry weight obtained by the strain Rhodococcus ruber that was $7.83 \pm 0.05$ $\mathrm{mg} / \mathrm{mL}$, increased bacterial dry weight was correlated with the use of oil in the environment (Figure 1). These results were interesting compared with those obtained by Gao et al. (2015), which used 11 bacteria strains isolated from deep-sea sediments of South Mid-Atlantic Ridge to evalute their ability to degrade oil by incubating crude oil as a carbon source for 20 days. Different strains degraded $48-88 \%$ of the crude oil and and five strains can degrade more than $60 \%$ of the crude oil.

Bacterial strains Rhodococcus ruber, Alcaligenes faecalis and Cellulosimicrobium sp. were demontrated thier ability to utilize crude petroleum as the sole source of carbon and energy.

\subsection{Chemical profile of biosurfactants}

\subsubsection{UV-Visible spectrophotometer analysis and Thin Layer Chromatography (TLC)} analysis

biosurfactant samples due to the positive response by the appearance of absorption peaks in the ultraviolet spectrum. Characterization by TLC revealed pink spots with frontal ratios (Rf) of $0.63,0.64$ and 0.63 for the biosurfactants produced by Rhodococcus ruber, Alcaligenes faecalis and Cellulosimicrobium sp., respectively, when sprayed with the ninhydrin reagent, indicating the presence of amino acids (Figure 2). The same profile of TLC was reported by Das et al. (2008), who studied a lipopeptide biosurfactant produced by Bacillus circulans. No spots were observed after spraying with the anthrone reagent which indicated the absence of sugar fractions. The above results confirmed the lipopeptide nature of the bio-surfactants which has been reported for other bacterial strains by Sriram et al. (2011) and Bezza and Chirwa (2015).

\subsubsection{Protein and lipid contents}


1 The protein and lipid contents of biosurfactant were differed in the biosurfactants. The

2 protein content in biosurfactants produced by Rhodococcus ruber, Alcaligenes faecalis and

3 Cellulosimicrobium were $10.46 \pm 0.39,7.51 \pm 0.30$ and $4.32 \pm 0.21 \%$, respectively. As for the

4 lipid, the highest content was noted for the biosurfactant produced by Rhodococcus ruber

5 which was $64.16 \pm 2.56 \%$, whereas the lower levels were detected for the biosurfactants

6 produced by Cellulosimicrobium sp. and Alcaligenes faecalis $(59.0 \pm 3.5 \%, 53.33 \pm 2.88 \%$, respectively). Sharma, et al. (2015) were indicate that the biosurfactant obtained from Bacillus pumilus DSVP18 grown on Potato Peels was composed of $14.7 \%$ protein and $18 \%$ lipid. These results confirm that the biosurfactants produced by Rhodococcus ruber, Alcaligenes faecalis and Cellulosimicrobium were indeed lipopeptides.

\subsubsection{Fourier Transform Infrared Spectroscopy (FTIR) Characterization}

FTIR characterization of biosurfactants from the three isolates Rhodococcus ruber, Alcaligenes faecalis and Cellulosimicrobium sp. showed identical spectra with varying absorption bands ranging from 3400 and $550 \mathrm{~cm}^{-1}$ (Figure 3). This similarity indicates that all biosurfactants have the same chemical nature. As shown in Figure 3, the FTIR spectra of the purified biosurfactants from the three stains showed strong absorbing bands at 3082 and 3312 $\mathrm{cm}^{-1}$ following elongation of the functional group $\mathrm{NH}$ and $\mathrm{OH}$ group, which was a characteristic of carbon-containing compounds with amine groups.The presence of an aliphatic chain was indicated by the C-H bonds of 2943 and $1439-1385 \mathrm{~cm}^{-1}$. The strong absorption band at $1653 \mathrm{~cm}^{-1}$ was due to the amide band (C-O stretch in the peptide bond). Peaks around $1700 \mathrm{~cm}^{-1}$ represent the $\mathrm{C}=\mathrm{O}$ grouping. Stretching groups $\mathrm{C}-\mathrm{O}$ and $\mathrm{C}-\mathrm{O}-\mathrm{C}$ were also present in the 1223 and $1063 \mathrm{~cm}^{-1}$ ranges respectively.

The IR absorption diagram also revealed the presence of peptide and carboxyl groups that confirms their lipopeptide nature (Sousa et al., 2014; Sivapathasekaran et al., 2009; Sivapathasekaran et al., 2010; Sriram et al., 2011). Compared with a standard commercial 
1 surfactin sample from Sigma-Chemical, Al-Wahaibi et al. (2014) reported the presence of

2 similar functional groups (amide, peptides and aliphatics) in surfactin. This indicates that our

biosurfactants and surfactin both absorbed at approximately the same wave number positions and showed anoverlapping pattern. This type of FTIR spectra is characteristic of lipopeptides, thus confirming the lipopeptide nature of the biosurfactants produced by the studied strains.

\subsection{Biological activities of the biosurfactants}

\subsubsection{The antimicrobial activity}

The antimicrobial properties of the biosurfactants produced micro-organisms of terrestrial origin have been widely reported. However, there have a little reports on microbial biosurfactants from marine origin (Das et al., 2008). In addition, there are no reports on antimicrobial activity of biosurfactants produced by Rhodococcus ruber, Alcaligenes faecalis and Cellulosimicrobium sp. isolated from Soummam wadi sediments.

The results of the antibacterial activity of these biosurfactants against bacteria SARM ATCC 43300, S. aureus NCCB 9163, E. coli ATCC 25922, P. aeroginosa ATCC 27853 and against fungi A. niger 939N, A. flavus NRRL 3251, A. parasiticus CB 5, A. ochraceus NRRL 3174 and C. albicans are all represented in Table 2.

The biosurfactants produced by Rhodococcus ruber showed higher activity against bacterial strains than against fungal ones. The clear zones presented a mean value of $18.33 \pm 0.57$ and 16.33 \pm 0.57 for A. flavus NRRL 3251 and A. parasiticus CB 5, respectively (Table 2). While for other fungal strains, they showed lower activity where clear zones diameters ranging from $11.66 \pm 0.57$ to $12.66 \pm 0.57 \mathrm{~mm}$. The inhibition zones indicated that antimicrobial activity of the compounds against Staphylococcus aureus showed a mean value of $12.66 \pm 0.57 \mathrm{~mm}$. The E. coli ATCC 25922 strain was the most sensitive with a clear zones diameter of $14.66 \pm 0.57$ $\mathrm{mm}$ while for $P$. aeroginosa ATCC 27853 the mean clear zones diameter was $10.66 \pm 0.57 \mathrm{~mm}$. 
1 The activity against fungi strains was higher when compared to bacterial ones. These results

2 are important since some these microorganisms have natural resistance to synthetic antibiotics. The isolated biosurfactants showed activity against both bacterial strains and fungi strains. Most of the lipopeptide biosurfactant showed activity against multidrug resistant pathogenic bacterial strains (Kitamoto et al., 1993; Singh and Cameotra2004;Das et al., 2008). However, antifungal action of biosurfactant against was scarcely reported.

\subsubsection{Antioxidant activity of biosurfactants}

All the biosurfactants studied showed lower antioxidant activity than the positive standard used (BHA) which gave the $\mathrm{IC}_{50}$ values of $7.1 \pm 0.2$ and $11.2 \pm 0.3 \mu \mathrm{g} / \mathrm{mL}$ in the $\mathrm{DPPH}^{\circ}$ and the phosphomolybdate tests respectively. The results of the phosphomolybdate test revealed that the most important reductive activity was found for the biosurfactant produced by Rhodococcus ruber $(1363.6 \pm 3.2 \mu \mathrm{g} / \mathrm{mL})$ and Alcaligenes faecalis $(1445.8 \pm 1.5 \mu \mathrm{g} / \mathrm{mL})$ with a significant difference at $P<0.05$ compared to the biosurfactant produced by Cellulosimicrobium sp. $(1661.3 \pm 5.8 \mu \mathrm{g} / \mathrm{mL})$.

The radical scavenging potential of the biosurfactants was carried with DPPH scavenging, the results were presented in the Table 3.The biosurfactant isolated from Alcaligenes faecalis showed better scavenger activity with an $\mathrm{IC}_{50}$ of $666.6 \pm 0.1 \mu \mathrm{g} / \mathrm{mL}$ with a significant difference at $P<0.05$ than the biosurfactants produced by Rhodococcus ruber $(823.8 \pm 0.6$ $\mu \mathrm{g} / \mathrm{mL}$ ) and Cellulosimicrobium sp. $(906.1 \pm 0.7 \mu \mathrm{g} / \mathrm{mL})$. Similar results have been reported by Bhosale et al. (2014) where their results indicate that lipopeptide biosurfactant from Klebsiella pneumoniae MSO-32 showed maximum scavenging effect on DPPH in the range of $76-78 \%$ at $10 \mathrm{mg} / \mathrm{ml}$.

\subsubsection{Metal biosorption activity}

The results of Lead metal chelation by the biosurfactants isolated from the studied strains at different $\mathrm{pH}$ values is shown in Table 4. Qe is the biosorption capacity of the Lead metal, 
1

expressed in milligram of lead per gram of biosurfactant.The results obtained showed the capacity of all biosurfactants to chelate the lead at different $\mathrm{pHs}$, which has also shown its influence on this metal biosorption. Indeed, better biosorption was recorded at neutral $\mathrm{pH}(\mathrm{pH}$ = 7) with a rate of $74.91 \pm 2.1 \mathrm{mg} / \mathrm{g}$ of biosurfactant produced by Rhodococcus ruber, followed by Cellulosimicrobium sp. with a quantity of $73.79 \pm 1.84 \mathrm{mg} / \mathrm{g}$ of biosurfactant. While at this $\mathrm{pH}$ we recorded the lowest biosorption capacity of lead with a content of $45.34 \pm$ $2.04 \mathrm{mg} / \mathrm{g}$ biosurfactant produced by Alcaligenes faecalis.

At acidic $\mathrm{pH}(\mathrm{pH}=3)$, we observed a decrease in chelation for the biosurfactants produced by Rhodococcus ruber and Cellulosimicrobium sp. Nevertheless, we recorded a significant lead biosorption of $66.94 \pm 1.64 \mathrm{mg} /$ for the biosurfactant produced by Alcaligenes faecalis.

Biosurfactant biosorption capacity of heavy metals has been described by some researchers (Miller, 1995;Das et al., 2009). The biosorption capacity depends on the structures and functional groups of the adsorbent and the state, the size and energy of metal ions (Maalej, et al., 2014; Sarubbo et al., 2015). It has been reported that compounds with structures containing two or more of the following functional groups: $\mathrm{OH},-\mathrm{COOH}, \mathrm{C}=\mathrm{O}$, -NR2, $-\mathrm{S}-$, and -O- may show metal chelation activity (Qi et al., 2005).

\section{Conclusion}

In this study, Alcaligenes faecalis, Rhodococcus ruber and Cellulosimicrobium sp. isolated from Soummam wadi sediment were active crude petroleum degraders and biosurfactant producers. Their biosurfactants were mainly lipopeptide and were found to exhibit good metal biosorption, antimicrobial and antioxidant activities evaluated by different tests. This bacterial isolate may open up avenues for biosurfactants commercial feasibility in bioremediation of petroleum spills. Thus, their bioactive molecules can furnish a choice to the current chemical compounds and they may also find applications in many biotechnological and biopharmaceutical applications due to their biological properties. Future work should be 
1 carried out in order to investigate the chemical structure and cellular toxicity of these

2 compounds.

\section{Acknowledgments}

4 This work was supported by a grant from the Ministry of High Education and Scientific

5 Research of Algeria. All authors thank everyone who contributed to the realization of this 6 work.

\section{References}

Al-Wahaibi, Y., Joshi, S., Al-Bahry, S., Elshafie, A., Al-Bemani, A., Shibulal, B. 2014. Biosurfactant production by Bacillus subtilis B30 and its application in enhancing oil recovery. Colloids and Surfaces B: Biointerfaces. 114: 324-333.

Banat, I.M., Franzetti, A., Gandolfi, I., Bestetti, G., Martinotti, M.G., Fracchia, L., Smyth, T.J., Marchant, R. 2010. Microbial biosurfactants production, applications and future potential. Applied Microbiology and Biotechnology. 87: 427-444.

Barbato, M., Scoma, A., Mapelli, F., De Smet, R., Banat, I.M., Daffonchio, D., Boon, N. and Borin, S. 2016. Hydrocarbonoclastic Alcanivorax isolates exhibit different physiological and expression responses to n-dodecane. Front. Microbiol. I doi: 10.3389/fmicb.2016.02056.

Bezza, F.A., Chirwa, E.M.N. 2015. Production and applications of lipopeptide biosurfactant for bioremediation and oil recovery by Bacillus subtilis CN2. Biochemical Engineering Journal. 101: 168-178.

Bhosale, H.J., Kadam, T.A., Phulari, S. 2014. Evaluation of antimicrobial activity and radical scavenging potential of lipopeptidebiosurfactant from Klebsiellapneumoniae MSO32. Journal of Pharmacy Research .8(2): 139-143. 
1 Bligh, E.G., Dyer, W.J. 1959. A rapid method of total lipid extraction and purification. Canadian journal of biochemistry and physiology. 37(8): 911-917.

Bradford, M.M. 1976. A rapid and sensitive method for the quantitation of microgram quantities of protein utilizing the principle of protein-dye binding. Analytical Biochemistry. 72(1-2): 248-254.

Brahmi, F., Adjaoud, A., Marongiu, B., Falconieri, D., Yalaoui-Guellal, D., Madani, K., Chibane, M. 2016. Chemical and biological profiles of essential oils fromMenthaspicata L. leaf from Bejaia in Algeria. Journal of Essential Oil Research. 28(3): 211-220.

Brahmi, F., Madani, K., Dahmoune, F., Rahmani, T., Bousbaa, K., Oukmanou, S., Chibane, M. 2012. Optimisation of solvent extraction of antioxidants (phenolic compounds) from Algerian mint (Menthaspicata L.). Pharmacognosy Communications 2(4): 72-86.

Carpentier, S., Jumeau, S., Moilleron, R. 1999. Mobilisation des polluants lors de la mise en dépôt des sédiments fluviaux contaminés. Crève, Université Paris XIIVal de Marne. Créteil. $185 \mathrm{p}$

Chaillan, F., Le Fleche, A., Bury, E., Phantavong, Y., Grimont, P., Saliot, A., Oudot, J. 2004. Identification and biodegradation potential of tropical aerobic hydrocarbon degrading microorganisms. Research in Microbiology. 155(7): 587-595.

Cunqi, L., Jianjian, L.and Hepeng, L. 2007. Landward changes of soil enzyme activities in a tidal flat wetland of the Yangtze River Estuary and correlations with physico-chemical factors. Acta Ecologica Sinica. 27(9): 3663-3669.

Das, P., Mukherjee, S., Sen, R. 2008. Antimicrobial potentials of a lipopeptide biosurfactant derived from a marine Bacillus circulans. Journal of Applied Microbiology, 104(6):1675-1684. 
1 Das, P., Mukherjee, S., Sen, R. 2009. Biosurfactant of marine origin exhibiting heavy metal remediation properties. Bioresource technology. 100(20): 4887-4890.

De Almeida, D.G., Soares Da Silva, R.C.F., Luna, J.M., Rufino, R.D., Santos, V.A., Banat, I.M. and Sarubbo, LA. 2016. Biosurfactants: Promising Molecules for Petroleum Biotechnology Advances. Front. Microbiol.7:1718. doi.org/10.3389/fmicb.2016.01718

Fracchia, L., Banat, JJ., Cavallo, M., Ceresa, C. and Banat, I M. 2015. Potential therapeutic applications of microbial surface-active compounds. AIMS Bioengineering. 2 (3): 144162. doi: 10.3934/bioeng.2015.3.144.

Gao, X., Gao, W., Cui, Z., Han, B., Yang, P., Sun, C. and Zheng, L. 2015. Biodiversity and degradation potential of oil-degrading bacteria isolated from deep-sea sediments of South Mid-Atlantic Ridge. Marine pollution bulletin. 97(1-2): 373-380.

Hwang, B.K. and Lee, J.Y. 2002. Diversity of antifungal actinomycetes in various vegetative soils of Korea. Canadian journal of microbiology. 48(5): 407-417.

Ijah, U.J.J., Antai, S.P. 2003. Removal of Nigerian light crude oil in soil over a 12 month period. International Biodeterioration and Biodegradation. 51: 93-99.

Kitamoto, D., Yanagishita, H., Shinbo, T., Nakane, T., Kamisawa,C. and Nakahara, T. 1993. Surface-active propertiesand antimicrobial activities of mannosylerythritol lipids asbiosurfactants produced by Candida antarctica. J Biotechnol. 29: 91-96.

Kretschmar, E. I., Keijer, H., Nelemans, P. and Lamersdorf, N. 2008. Investigating physicochemical sediment conditions at decayed wooden pile foundation sites in Amsterdam. International Biodeterioration \& Biodegradation. 61(1): 85-95. 
1 Maalej, H., Moalla, D., Boisset, C., Bardaa, S., Ayed, H. B., Sahnoun, Z., ... , Hmidet, N. 2014. Rhelogical, dermal wound healing and in vitro antioxidant properties of exopolysaccharide hydrogel from Pseudomonas stutzeri AS22. Colloids and Surfaces B: Biointerfaces. 123: 814-824.

Miller, R.M. 1995. Biosurfactant-facilitated remediation of metal-contaminated soils. Environmental Health Perspectives. 103(supp1):59.

Mulligan, C.N., Sharma, S. K., Mudhoo, A. 2014. Biosurfactants: research trends and applications. CRC press. 321p.

Noparat, P., Maneerat, S., Saimmai, A. 2014. Utilization of palm oil decanter cake as a novel substrate for biosurfactant production from a new and promising strain of Ochrobactrumanthropi 2/3. World Journal of Microbiology and Biotechnology. 30(3): 865-877.

Qi, H., Zhao, T., Zhang, Q., Li, Z., Zhao, Z., Xing, R. 2005. Antioxidant activity of different molecular weight sulfated polysaccharides from Ulva pertusaKjellm (Chlorophyta). Journal of Applied Phycology. 17(6): 527-534.

Richards L.A. 1969. Diagnostic and improvement of saline and alkaline soils. Agr. Handbook.

Sarubbo, L.A., Rocha Jr, R.B., Luna, J.M., Rufino, R.D., Santos, V.A. And Banat, I. M. 2015. Some aspects of heavy metals contamination remediation and role of biosurfactants. Chemistry and Ecology. 31(8): 707-723, doi: 10.1080/02757540.2015.1095293

Samanta, S.K., Singh, O.V., Jain, R.K. 2002. Polycyclic aromatic hydrocarbons: environmental pollution and bioremediation. Trends in Biotechnology. 20(6): 243-248. 
1 Sharma, D., Ansari, M. J., Gupta, S., Al Ghamdi, A., Pruthi, P., \& Pruthi, V. 2015. Structural characterization and antimicrobial activity of a biosurfactant obtained from Bacillus pumilus DSVP18 grown on potato peels. Jundishapur journal of microbiology. 8(9).e21257, doi: 10.5812/jjm.21257

Shuhong, Y., Meiping, Z., Hong, Y., Han, W., Shan, X., Yan, L., Jihui, W. 2014. Biosorption of $\mathrm{Cu}^{2+}, \mathrm{Pb}^{2+}$ and $\mathrm{Cr}^{6+}$ by a novel exopolysaccharide from Arthrobacter ps5. Carbohydrate polymers. 101: 50-56.

Singh, P.; Cameotra, S.S. 2004. Potential applications of microbial surfactants in biomedical sciences. Trends in Biotech.. 22, 142-146.

Sivapathasekaran, C., Mukherjee, S., Samanta, R., Sen, R. 2009. High-performance liquid chromatography purification of biosurfactant isoforms produced by a marine bacterium, Analytical and Bioanalytical Chemistry. 395(3): 845-854.

Sivapathasekaran, C., Mukherjee, S., Sen, R. 2010. Matrix assisted laser desorption ionization-time of flight mass spectral analysis of marine lipopeptides with potential therapeutic implications.International Journal of Peptide Research and Therapeutics. 16(2): 79-85.

Smyth, T.J., Rudden, M., Tsaousi, K., Marchant, R., Banat, I.M. 2014. Protocols for the Detection and Chemical Characterisation of Microbial Glycolipids.Hydrocarbon and Lipid Microbiology Protocols: Biochemical Methods. 29-60.

Sousa, M., Dantas, I.T., Feitosa, F.X., Alencar, A.E.V., Soares, S.A., Melo, V.M.M., Goncalves, L.R.B., Santana, H.B. 2014. Performance of a biosurfactant produced by Bacillus subtilis LAMI005 on the formation of oil/biosurfactant/water emulsion: study 
of the phase behaviour of emulsified systems, Brazilian Journal of Chemical Engineering. 31(3): 613-623.

Sriram, M.I., Kalishwaralal, K., Deepak, V., Gracerosepat, R., Srisakthi, K., Gurunathan S. 2011. Biofilm inhibition and antimicrobial action of lipopeptide biosurfactant produced by heavy metal tolerant strain Bacillus cereus NK1, Colloids and Surfaces B: Biointerfaces. 85(2): 174-181.

Stauffert, M. 2011. Dynamique des communautés microbiennes en réponse à une contamination pétrolière dans des sédiments bioturbés. Thèse de Doctorat, L'université de Pau et des Pays de l'Adour.278p.

Técher, D. 2011. Réhabilitation de sols pollués par des HAP grâce aux bactéries associées à la rhizosphère de Miscanthus X giganteus, Thèse de doctorat, Université Paul Verlaine de Metz.

Wicke, C., Hüners, M., Wray, V., Nimtz, M., Bilitewski, U., Lang, S. 2000. Production and structure elucidation of glycoglycerolipids from a marine sponge-associated Microbacterium species. Journal of Natural Products. 63(5):621-626.

Yalaoui-Guellal D., Brahmi F., Touati A., De Champs C., Banat I.M. and Madania K. 2018. Production of Biosurfactants by Hydrocarbons Degrading Bacteria Isolated from SoummamWatershed Sediments of Bejaia in Algeria. Environmental Progress \& Sustainable Energy. 37(1), 189-195. doi 10.1002/ep.12653.

Zhang, W., Song, L. S., Ki, J. S., Lau, C. K., Li, X. D. and Qian, P. Y. 2008. Microbial diversity in polluted harbor sediments II: sulfate-reducing bacterial community assessment using terminal restriction fragment length polymorphism and clone library of dsrAB gene. Estuarine, Coastal and Shelf Science. 76(3): 682-691. 


\section{Journal Pre-proof}

1 Zhou, Y. (2009). Évaluation de la biodisponibilité des métaux dans les sédiments. Rapport d'étude. Agence de l'eau Artois-Picardie et Université des Sciences et technologie de

3 Lille I, UMR

Géosystémes, p14.

Disponible

$a u$. http://www.eauartoispicardie.fr/IMG/pdf/evaluation_de_la_biodisponibilite_des_metau

5 x_dans_les_sed iments. pdf. 0,1 . 


\section{Joumal Pre-proof}

Table 1: Different microorganisms tested with biosurfactants.

\begin{tabular}{lll}
\hline & Microorganisms tested & References \\
\hline Gram+ Bacteria & Methicillin-resistant Staphylococcus aureus (SARM) & ATCC 43300 \\
& Staphylococcus. aureus & NCCB 9163 \\
Gram- Bacteria & Escherichia coli & ATCC 25922 \\
& Pseudomonas aeroginosa & ATCC 27853 \\
Filamentous fungi & Aspergillus niger & 939N \\
& Aspergillus flavus & NRRL 3251 \\
& Aspergillus parasiticus & CB 5 \\
& Aspergillus ochraceus & NRRL 3174 \\
Yeast & Candida albicans & ATCC 1024 \\
\hline
\end{tabular}

ATCC: American Type Culture Collection

NRRL: Netherlands Culture Collection of Bacteria 
Table 2: Antimicrobial activity of crude biosurfactant produced by Rhodococcus ruber, Alcaligenes faecalis and Cellulosimicrobium.

\section{Antimicrobial zone diameter (mm)}

Biosurfactant produced by

Microorganismes Cellulosimicrobium sp. Alcaligenes faecalis Rhodococcus ruber

\begin{tabular}{llll}
\hline Bactrial strains & & & \\
SARM ATCC 43300 & $12.66 \pm 0.57^{\mathrm{b}}$ & $11.66 \pm 0.57^{\mathrm{c}}$ & $11.66 \pm 0.57^{\mathrm{c}}$ \\
S. aureusNCCB 9163 & $11.66 \pm 0.57^{\mathrm{b}, \mathrm{c}}$ & $12.66 \pm 0.57^{\mathrm{b}}$ & $10.66 \pm 0.57^{\mathrm{c}}$ \\
E. coli ATCC 25922 & $10,66 \pm 0,57^{\mathrm{c}}$ & $12.66 \pm 0.57^{\mathrm{b}}$ & $14.66 \pm 0.57^{\mathrm{a}}$ \\
P. aeroginosaATCC 27853 & $10.66 \pm 0.57^{\mathrm{c}}$ & $9.66 \pm 0.57^{\mathrm{c}}$ & $10.66 \pm 0.57^{\mathrm{c}}$ \\
Fungal strains & & & \\
A. niger939N & $11.66 \pm 0.57^{\mathrm{d}}$ & $11.66 \pm 0.57^{\mathrm{d}}$ & $12.66 \pm 0.57^{\mathrm{d}}$ \\
A. flavusNRRL 3251 & $15.66 \pm 0.57^{\mathrm{b}}$ & $18.33 \pm 0.57^{\mathrm{a}}$ & $16.66 \pm 0.57^{\mathrm{b}}$ \\
A. parasiticusCB 5 & $15.16 \pm 0.57^{\mathrm{c}}$ & $16,16 \pm 0,57^{\mathrm{b}, \mathrm{c}}$ & $16.33 \pm 0.57^{\mathrm{b}}$ \\
A. ochraceus NRRL 3174 & $11.66 \pm 0.57^{\mathrm{d}}$ & $11.66 \pm 0.57^{\mathrm{d}}$ & $11.66 \pm 0.57^{\mathrm{d}}$ \\
C. albicansATCC 1024 & $11.66 \pm 0.57^{\mathrm{d}}$ & $11.66 \pm 0.57^{\mathrm{d}}$ & $12.33 \pm 0.57^{\mathrm{d}}$ \\
\hline
\end{tabular}

The values of clear zone diameter represent the mean $\pm S D$ of three independent readings.

Statistically significant difference with respect to crude biosurfactant $p<0.05$ 
Table 3: $\mathrm{IC}_{50}$ values $(\mu \mathrm{g} / \mathrm{mL})$ of various tests of antioxidant activity of the biosurfactants studied.

\section{DPPH $^{*} \quad$ Phosphpmolybdate test}

Biosurfactant isolated from Cellulosimicrobium sp.

$906.1 \pm 0.7^{\mathrm{d}}$

$1661.3 \pm 5.8^{\mathrm{d}}$

Biosurfactant isolated from Alcaligenes faecalis

$666.6 \pm 0.1^{\mathrm{b}}$

$1445.8 \pm 1.5^{\mathrm{c}}$

Biosurfactant isolated from Rhodococcus ruber

$823.8 \pm 0.6^{\mathrm{c}}$

$1363.6 \pm 3.2^{\mathrm{b}}$

BHA

$7.1 \pm 0.2^{\mathrm{a}}$

$11.2 \pm 0.3^{\mathrm{a}}$

BHA: Butylated Hydroxyanisole, Values shown are averages of three replicas \pm standard error. The different letters mean a significant difference at $p<0.05$. 


\section{Journal Pre-proof}

Table 4: Lead biosorption capacity by biosurfactants studied at different $\mathrm{pH}$.

\begin{tabular}{lcc}
\hline Biosurfactant origin & \multicolumn{2}{c}{ Qe (mg/g) } \\
& $\mathbf{p H}=7$ & $\mathbf{p H}=\mathbf{3}$ \\
\hline Cellulosimicrobium sp. & $73.79 \pm 1.84^{\mathrm{a}}$ & $57.25 \pm 1.81^{\mathrm{b}}$ \\
Alcaligenes faecalis & $45.34 \pm 2.04^{\mathrm{b}}$ & $66.94 \pm 1.64^{\mathrm{a}}$ \\
Rhodococcus ruber & $74.91 \pm 2.1^{\mathrm{a}}$ & $65.9 \pm 1.3^{\mathrm{a}}$ \\
\hline
\end{tabular}

Values shown are averages of three replicas \pm standard error.

The different letters mean a significant difference at $p<0.05$. 


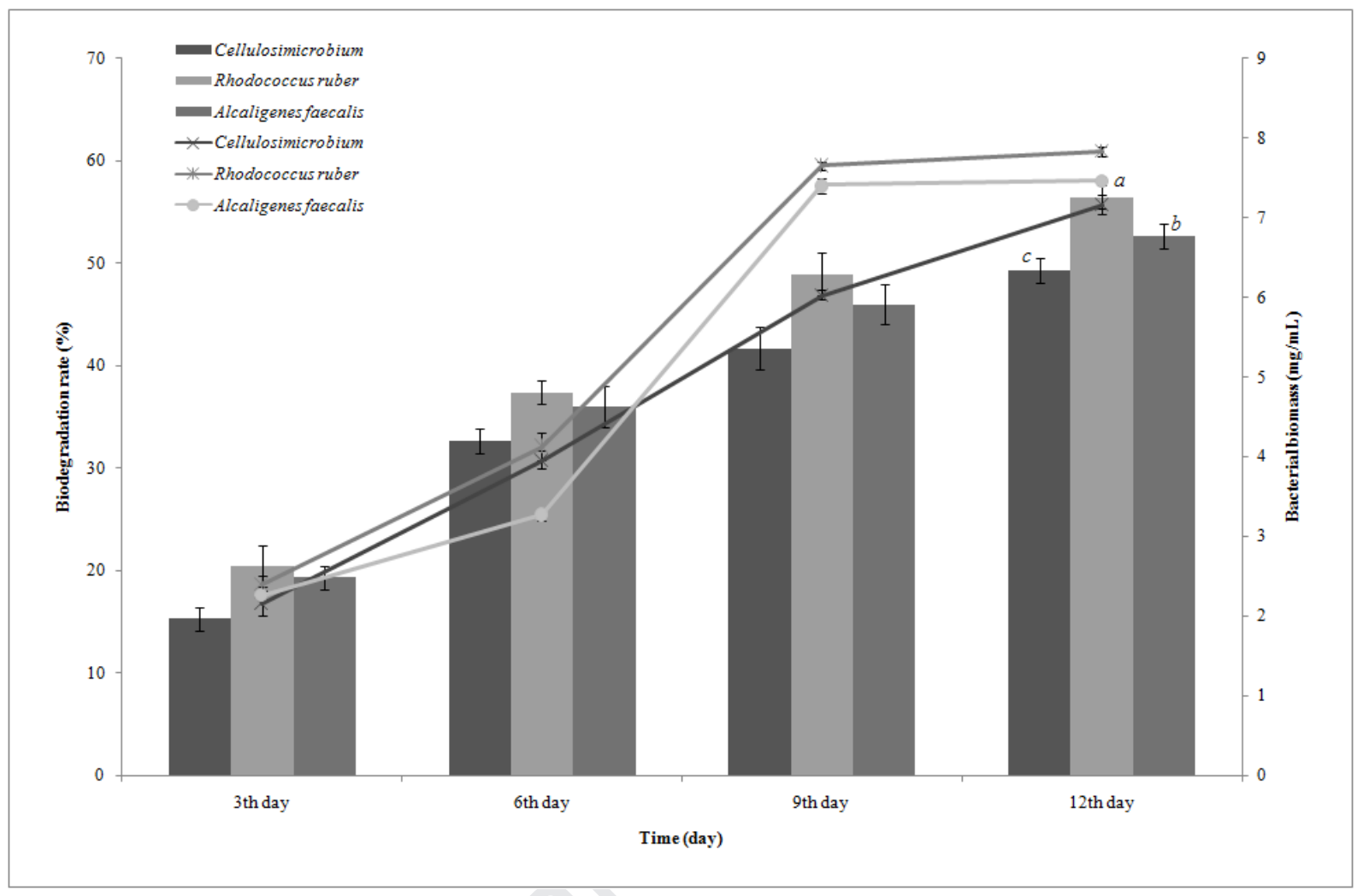

Figure 1. Biodegradation potential of crude petroleum and bacterial growth. The different letters: $\mathrm{a}, \mathrm{b}$ and $\mathrm{c}$ mean a significant difference at $p<0.05$. 


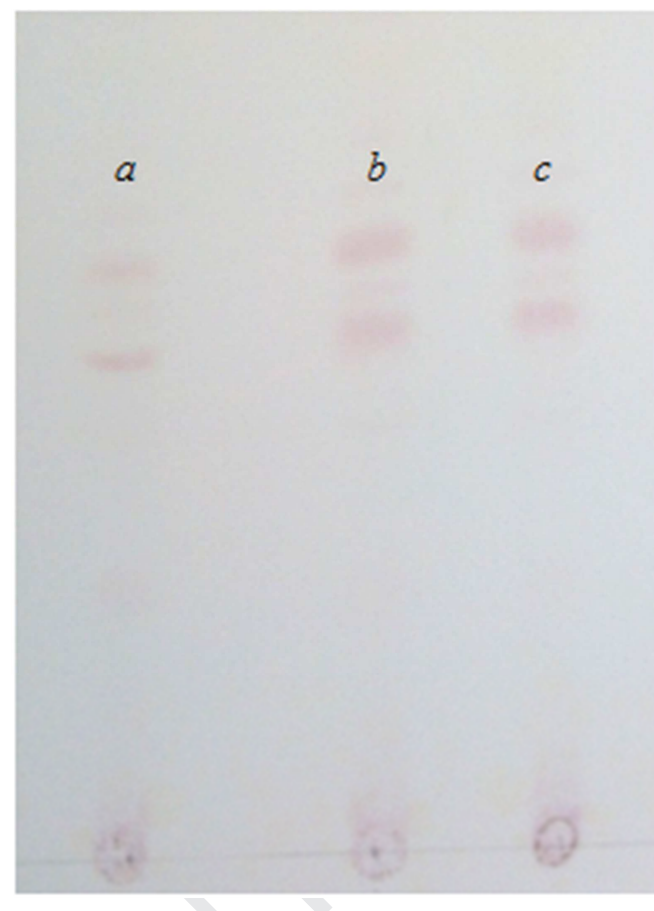

Figure 2.Thin layer chromatography of crude biosurfactants: lane a: crude biosurfactant fractions produced by Cellulosimicrobium sp., lane $b$ : crude biosurfactant fractions produced by Alcaligenes faecalis, lane $c$ : the crude biosurfactant fractions produced by Rhodococcus ruber 

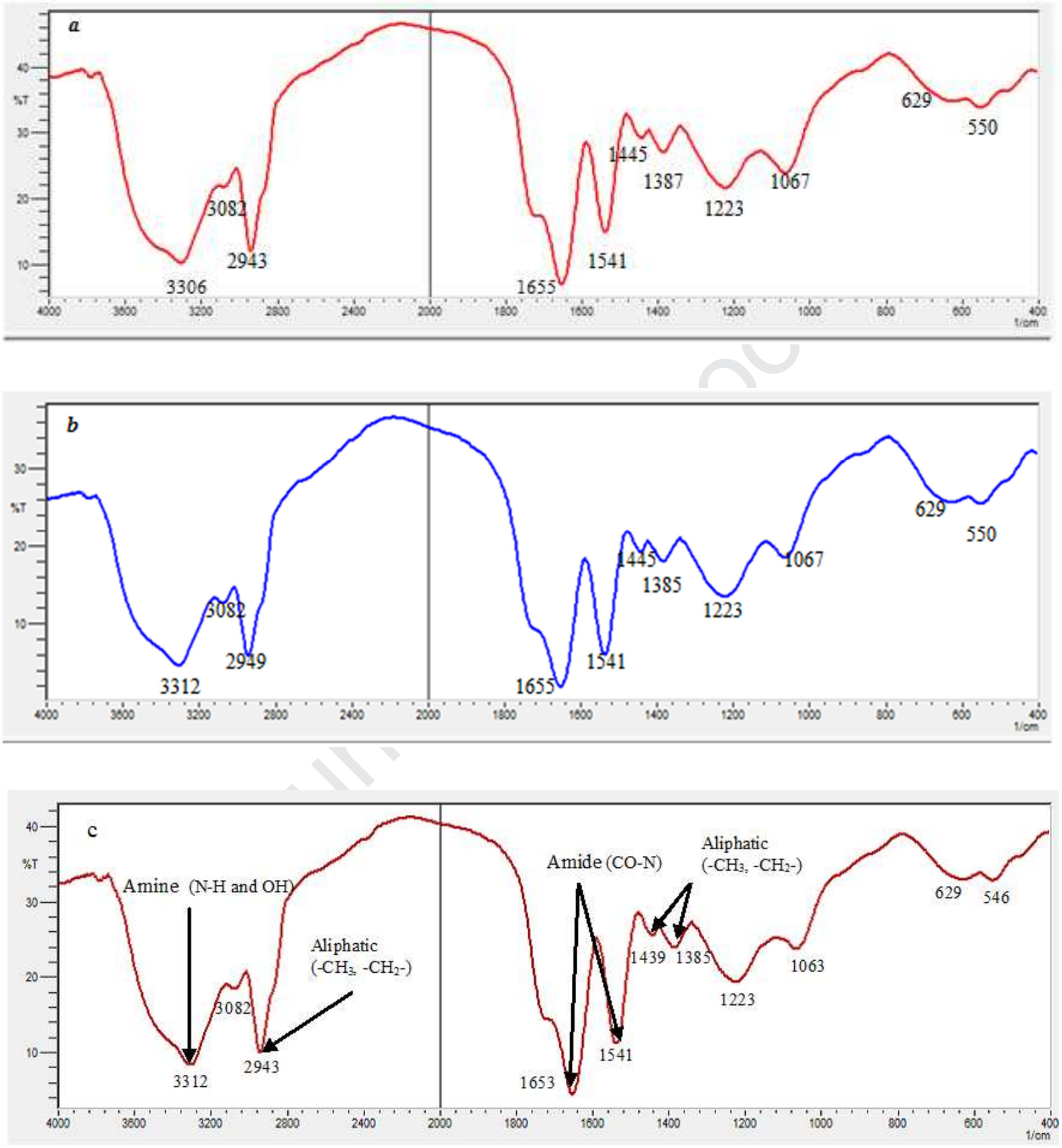

Figure 3. FTIR spectra of the purified biosurfactant samples produced by (a): Cellulosimicrobium sp., (b): Alcaligenes faecalis and (c): Rhodococcus ruber 


\section{Highlights}

- Best petroleum degradation was shown by Rhodococcus ruber from sediment shorelines.

- Chemical profile study of their biosurfactant indicates their lipopeptide nature.

-These biosurfactants showed higher antifungal activity than antibacterial ones.

- Also, these biosurfactant prove their biosorption capacity of lead at different $\mathrm{pH}$. 